PM アルミ合金のキャビテーションエロージョン特性

大㭷 真人, 由利浩一, 河野通

三菱マテリアル侏中央研究所，テ330大宫市北袋町1-297.

\title{
Cavitation Erosion Characteristics of Powder Metallurgy Aluminum Alloys
}

\author{
Masato Otsuki, Koichi Yuri and Tohru Kohno
}

Central Research Institute, Mitsubishi Materials Corp., 1-297 Kitabukuro-cho, Omiya 330.

Received June 21, 1994

Cavitation erosion resistance is an important mechanical property required to high-speed hydrodynamic machine parts materials such as oil pump rotor. In this study, vibratory cavitation erosion test was conducted on rapidly solidified powder Al-Si base alloys to investigate relations between cavitation erosion resistance and their composition or microstructure. It is confirmed that powder forged $\mathrm{Al}-\mathrm{Si}$ alloys containing large amount of transition metals such as $\mathrm{Fe}$ or $\mathrm{Cr}$ has as good resistance to cavitation erosion as that of Fe base sintered alloy especially when the powder has fine microstructure owing to high cooling rate of the powder production. The cause of the high resistance to cavitation erosion can be attributed to that the matrix was dispersion strengthened by large amount of fine dispersoids of aluminides of $\mathrm{Fe}, \mathrm{Cr}$ and $\mathrm{Si}$.

\section{1 緒言}

$\mathrm{Al}-\mathrm{Si}$ 系急冷凝固アルミ合金粉末材は軽量かつ 強度, 耐摩耗性等の特性に優れ, 種々の機械部 品への適用が進められている。本材料をオイル ポンプロー夕等の高速流体機械部品に用いる場 合, 摺動部の耐摩耗性に加え, 流体のキャビ テーション現象により受ける衝撃に対する耐性 （耐キャビテーションエロージョン性）が重要 な要求特性となる. キャビテーション現象は流
体機械部品周りの高速流の減圧部に気泡 (キャビティ) が発生する現象であり，この 気泡の崩壇時に発生する衝撃波により生じる 損傷がキャビテーションエロージョンであ る. Photo.1にオイルポンプロータに発生した キャビテーションエロージョンの例を示す. キャビテーションエロージョンを生じる機械 部品の例としてはこの他に水力タービン, ス クリュープロペラ等がある。 


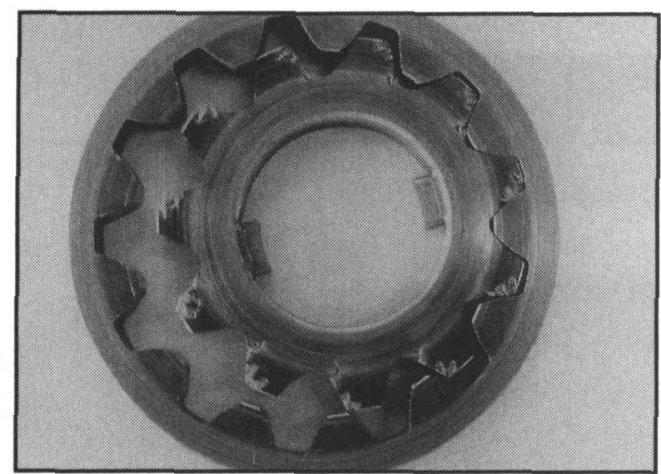

Photo.1 Example of cavitation erosion in oil pump rotor.

本研究では種々のAl-Si系急冷凝固アルミ合 金粉末材の耐キャビテーション損傷特性につ いて超音波振動試験法により評価を行い, そ の材料組成, 組織との関連について検討し た.

\section{2 試料および実験方法}

試料としてはTable 1 に示す粉末鍛造法によ り作製した数種類の $\mathrm{Al}-\mathrm{Si}$ 系急冷凝固アルミ合 金粉末材と, 比較材として一般的な溶製アル ミ合金材であるADC12アルミダイカスト材な らびにオイルポンプロータ材として実績のあ る鉄系焼結材を選んだ。粉末鍛造材について は, Table 1の組成の窒素ガスアトマイズ粉末を 室温金型成形によりプリフォームを作製し,

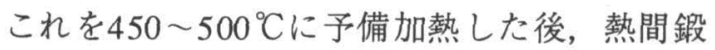
造を施し，また一部の材料については更に熱 処理を施した.

Table 1 Chemical composition and preparation of specimens used.

\begin{tabular}{|l:l|}
\hline \multicolumn{1}{|c|}{ Composision } & \multicolumn{1}{c|}{ Preparation } \\
\hline Fe-2Cu-0.5C & Sintered Fe alloy \\
Al-10Si-3Cu & Die cast ADC12-T6 \\
\hline Al-25Si-3Cu-1Mg-1Fe & Powder forged-T5 \\
\hdashline Al-20Si-3Cu-1Mg-4Fe & Powder forged-T5 \\
\hdashline Al-16Si-10Fe-2Cr & As powder forged \\
Al-16Si-10Fe-2Cr & As forged from $-75 \mu \mathrm{m}$ powder \\
\hline Al-16Si-10Fe-2Cr & As forged from $-45 \mu \mathrm{m}$ powder \\
\hline
\end{tabular}

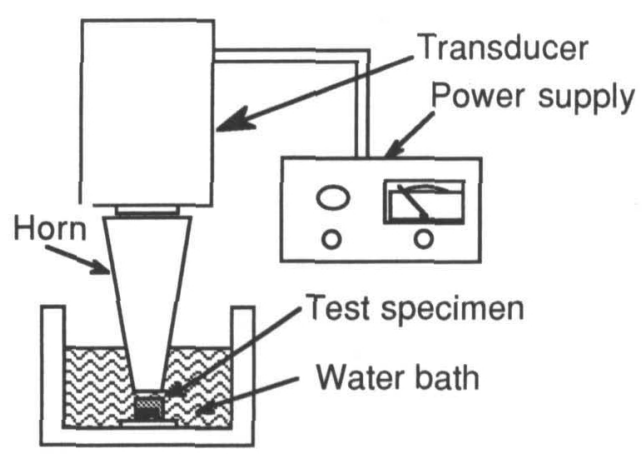

Fig. 1 Schematic of vibratory cavitation errosion test apparatus ( specimen dia. : $12 \mathrm{~mm}$, gap between specimen and horn : $0.8 \mathrm{~mm}$, vibration frequency : $20 \mathrm{kHz}$, amplitude : $35 \mu \mathrm{m}$, Test duration : $6 \mathrm{hrs}$, fluid : $50^{\circ} \mathrm{C}$ distilled water ).

耐キャビテーション損傷性の評価方法とし てはASTM G32にて規格化している方法1に 準じたFig. 1 に示す振動式キャビテーション 損傷試験装置を用い, 上述の試料より加工し た外径 $\phi 12 \mathrm{~mm}$ の円柱状試験片を水中に固定 し，その直上に設置した超音波振動ホーンの 振動によりキャビテーションを一定時間発生 させ, 試料表面に損傷を与え, 試料の重量減 から損耗体積を算出した. また試験後の損傷 面のSEM観察および断面組織観察により損耗 状態を調査した。

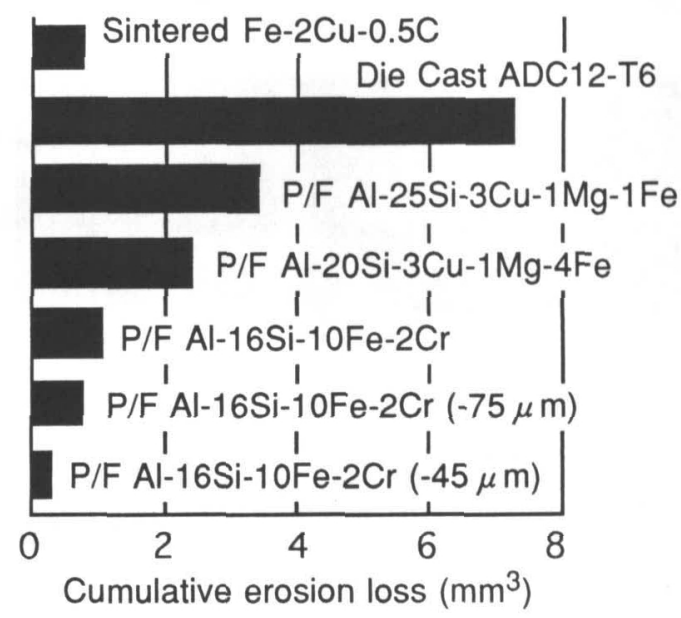

Fig. 2 Cavitation erosion loss of various specimens. 


\section{3 実験結果および考察}

Fig. 2 に各材料のキャビテーション損傷量の 比較を示す。まず比較材として評価した鉄系 焼結材のキャビテーション損傷量は非常に少 ないが，ADC12ダイカスト材は非常に損耗が 激しいことが判る。また高Si粉末鍛造材につ いてはアルミダイカスト材と比較すると, 損 傷量は少ないものの鉄系焼結材との比較では 劣っている。次に粉末鍛造材に於いて, $\mathrm{Si}$ 添 加量を減じ，代わりに遷移金属（Feおよび Cr）の添加量を増加させると，その損傷量は 減少する傾向にある。また細かい粒度の粉末 のみを原料に用いたものは更に向上し，鉄系 焼結材と同等もしくはそれ以上の特性が得ら れている.

Photo. 2 に試験後の試料損傷表面のSEM写真

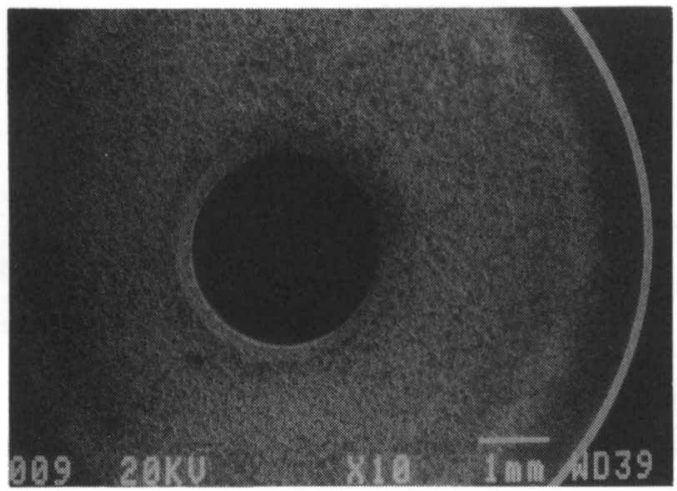

(a)

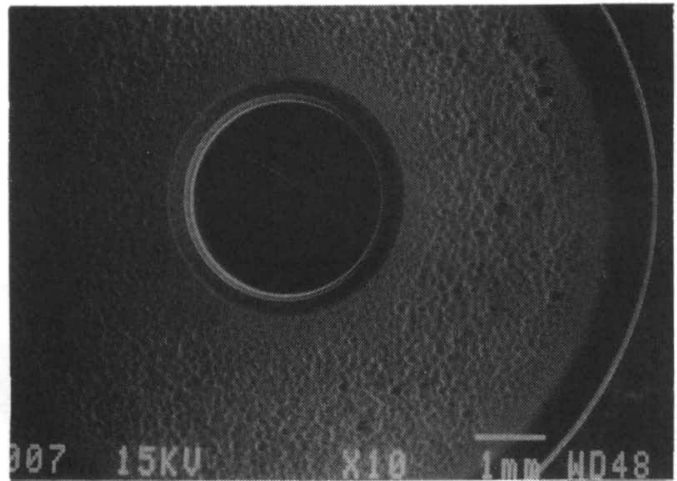

(c)
を示す、鉄系焼結材とアルミダイカスト材の 損傷状態を比較すると（Photo. 2-a, b），鉄系 焼結材の表面は比較的滑らかであるが，アル ミダイカスト材には非常に深い孔食が生じて いることが判る。また高 $\mathrm{Si}$ 粉末鍛造材の損傷 面 (Photo. 2-c) についてもアルミダイカスト 材と同様,深い孔食が生じていることが判 る. Photo. 3 にアルミダイカスト材と高Si 粉 末鍛造材の損傷面を含む垂直断面の光学顕微 鏡組織を示す。いずれも組織全体が損傷を受 けていることが判る。一方, $\mathrm{Al}-16 \mathrm{Si}-10 \mathrm{Fe}-2 \mathrm{Cr}$ 組成粉末鍛造材の損傷表面(Photo. 2-d)に於い ては，部分的な損傷を生じているものの，そ の他の部分は殆ど損傷していないことが判 る. Photo. 4 にこの損傷表面の拡大および損 傷面を含む垂直断面の光学顕微鏡組織を示

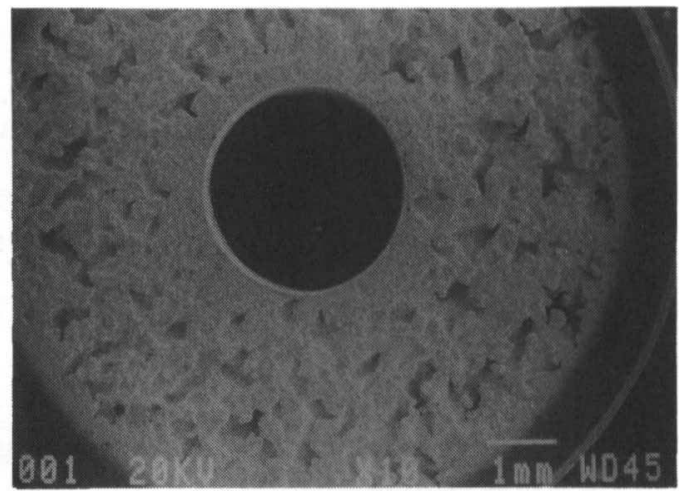

(b)

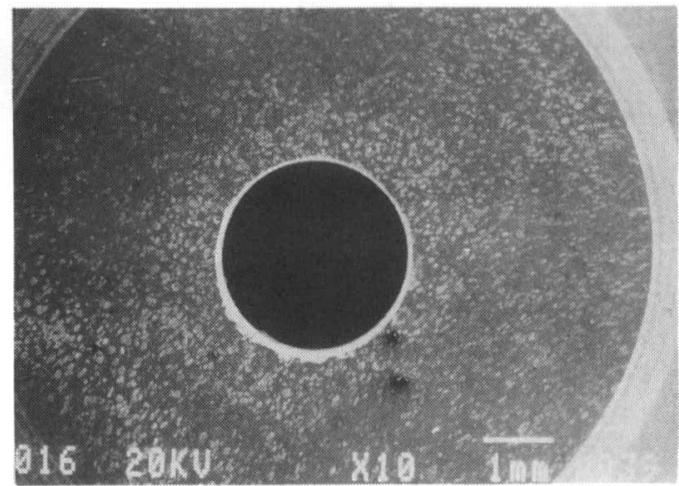

(d)

Photo. 2 SEM microphotos of surfaces of specimens after cavitation erosion test. (a) Sintered Fe-2Cu$0.5 \mathrm{C}$, (b) Die Cast ADC12-T6, (c) Powder forged Al-25Si-3Cu-1Mg-1Fe, (d) Powder forged $\mathrm{Al}-16 \mathrm{Si}-10 \mathrm{Fe}-2 \mathrm{Cr}$. 


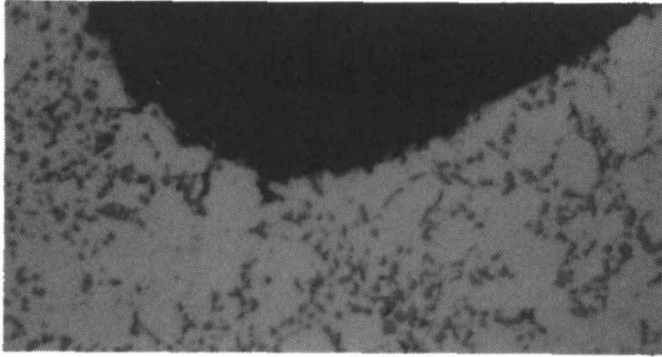

(a)

$50 \mu \mathrm{m}$

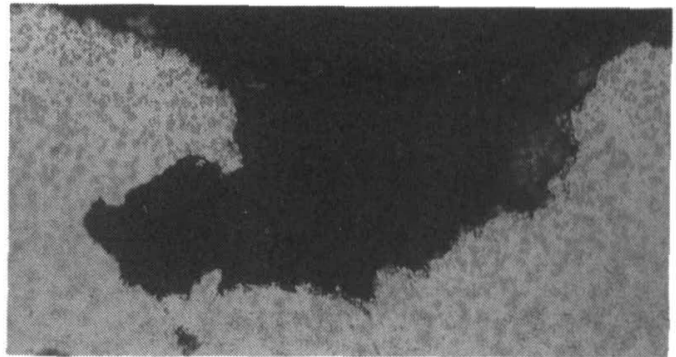

(b)

$50 \mu \mathrm{m}$

Photo. 3 Optical microstructures of near surfaces after erosion test of (a) Die Cast ADC12-T6, (b) Powder forged $\mathrm{Al}-25 \mathrm{Si}-3 \mathrm{Cu}-1 \mathrm{Mg}-1 \mathrm{Fe}$.

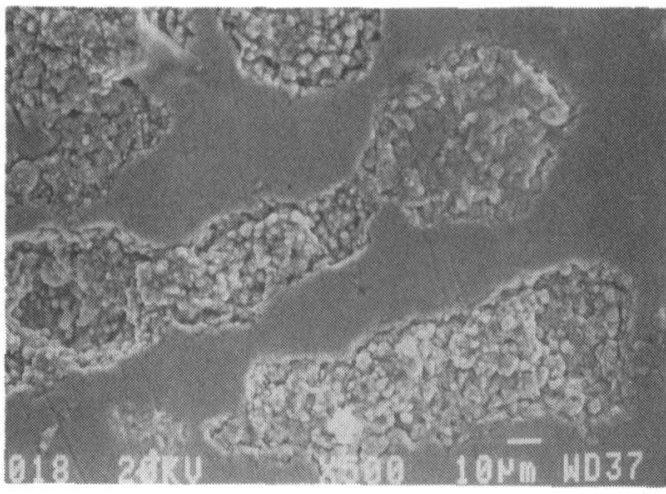

Photo. 4 (a) SEM microphoto. of near surface and (b) Optical microstructure of near surface after erosion test of powder forged $\mathrm{Al}-16 \mathrm{Si}-10 \mathrm{Fe}-2 \mathrm{Cr}$.
す. 損傷を受けているのは組織の粗い部分で あり, 微細組織部分は殆ど損傷していないこ とが判る. 組織の荒い部分は粗大な粉末から なる部分であり，微細組織部は細かい粉末か らなっている．この組織の違いはアトマイズ による粉末製造に際し, サイズの細かい粉末 ほどその比表面積が大きく, 冷却速度が高い 為に初晶 $\mathrm{Si}$ の成長が抑制されると共に, $\mathrm{Al}(\mathrm{Fe}, \mathrm{Cr}) \mathrm{Si}$ 系の金属間化合物が微細分散した組 織となり，逆に粒径の大きい粉末の冷却速度 は低く, 初晶Siや化合物相が粗大化した組織 となっていることによる.高Si粉末鍛造材は 硬質の初晶Si量が大量に分散しており，摩擦 摩耗に於いてはアルミダイカスト材等と比ベ ると格段に高い耐摩耗性を示すが2), 今回行っ た耐キャビテーション損傷性の評価に於いて

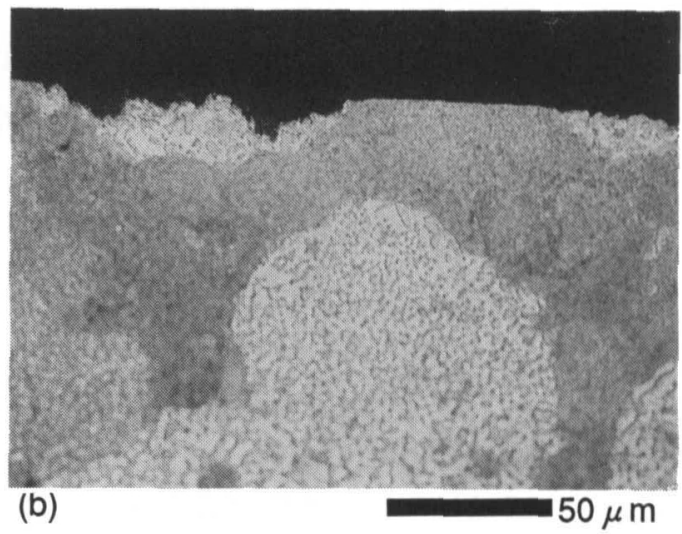

$50 \mu \mathrm{m}$ 


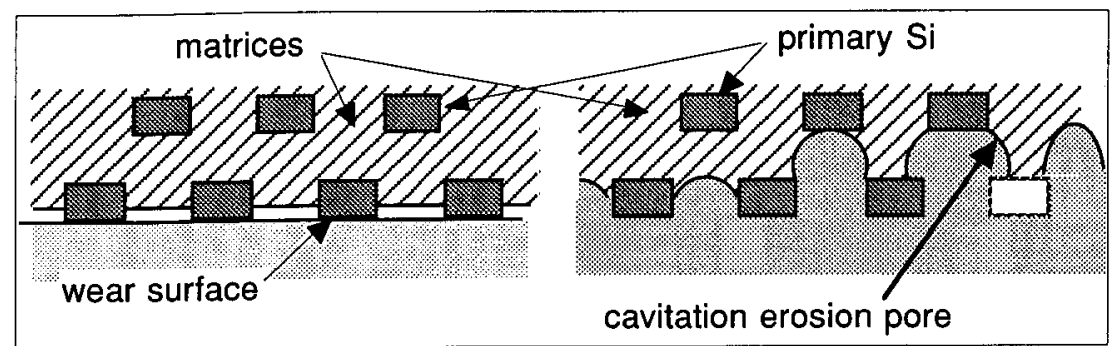

(a)

(b)

Fig. 3 Schematic of the comparison of mechanisms of (a) friction wear and (b) cavitation erosion of high Si Aluminum alloy.

く，かつ損傷が進行するにつれ初晶Siも脱落し てゆき，更に損傷が進むと考えられる。これ に対し遷移金属を添加することにより特に粉 末製造時の冷却速度の高い粉末はそのマト リックスが微細な分散化合物相により分散強 化され，硬さが上がっている為に損傷が減少 しているが，同じ組成であっても粗大粉末部 分に於いてはその様な強化機構が十分働いて いないと考えられる。

今回評価したいずれの粉末鍛造材について も，その損傷面の観察に於いて旧粉末粒界が 選択的に損傷を受け粉末が脱落している，或 いは旧粉末粒界が損傷の進行を抑えていると いう状況は見られなかった。これは粉末鍛造 により旧粉末表面酸化被膜の破壊分散が行わ れ，粉末間の結合が強固なものになっている と共に，旧粉末表面酸化被膜が非常に薄いこ とと, 破壊分散されている為に，損傷の進行 を抑えることに寄与していないことによるも のと考えられる。

\section{4 ま と め}

種々のAl-Si系急冷凝固アルミ合金粉末材お よび比較材の耐キャビテーション損傷特性に
ついて超音波振動試験法により評価を行い以 下の結果を得た.

1. 鉄系焼結材と比較してアルミダイカスト 材のキャビテーション損傷は激しく，また高 $\mathrm{Si}$ アルミ粉末鍛造材についてはアルミダイカ スト材と比較すると損傷量は少ないものの鉄 系焼結材との比較では劣っている.

2. 遷移金属の添加によりアルミ粉末鍛造材 の損傷量は減少し，また細かい粒度の粉末の みを原料に用いたものは更に向上し鉄系焼結 材と同等の特性が得られている。

3. 遷移金属を添加することにより特に粉末 製造時の冷却速度の高い粉末はそのマトリッ クスが微細な分散化合物相により分散強化さ れ，硬さが上がっている為に耐キャビテー ション損傷性が向上していると考えられる.

\section{文献}

1) 1987 Annual Book of ASTM Standards, ASTM,Vol 03.02 (1987) 187.

2) 大梘真人, 河野通: 粉体および粉末治金 37 (1991) 513. 